\title{
THE CAUSAL FACTORS OF BUGIS-BONE ACCENT INTERFERENCE ON THE PRONUNCIATION IN ENGLISH CONVERSATION
}

\author{
Nur Padhilah \\ Universitas Pendidikan Indonesia \\ nurpadhilah1995@gmail.com \\ Hamdan Juhannis \\ Universitas Islam Negeri Alauddin Makassar \\ hamdan@uin-Alauddin. \\ Sitti Nurpahmi \\ Universitas Islam Negeri Alauddin Makassar \\ Sitti.nurpahmi@uin-Alauddin.ac.id
}

\begin{abstract}
The research aims to identify the causal factors of the English Students' Accent interference on the pronunciation of English conversation. To meet the objective, the researchers adopted case study design by Cresswell. The data were gathered through the qualitative method based on Miles and Huberman's technique of data analysis. The research was undertaken in STAIN Watampone, Kabupaten Bone, from March 2017 to May 2017. The finding of the research showed that the the different phoneme areas of Bugis-Speaker with English Speakers and Bugis-Bone is strong/heavy accent are the causal factors that become the interference when the students speak English in English conversation. Referring to the description above, it informed that the students should be practice their English pronunciation of English conversation to avoid their native language interferences.
\end{abstract}

Keyword: Bugis- speakers, interferences, buginese accent

\section{A. INTRODUCTION}

$\mathrm{P}$ eople generally think that speak English with their local language accent isn't a matter but it is different for some English students in Bone. They sometimes felt shy to speak English because people (from other regions) frequently laugh their accent.

Some of them also have a problem to pronounce the English words. The researcher even found a teacher who stopped her students' conversation in the class because the student was difficult to pronounce some words and made the other one didn't understand what he said. It is also a challenge for English teachers who have students from Bugis-Bone or the teacher that teach in Bone.

A teacher has to prepare authentic and flexible teaching materials to the needs of students, so the material in the class is undoubtedly convenient to be used outside the classroom. If it is an English teacher who teach an English conversation material, he/she should be able to teach it well, or at least invite an English native speaker to be the students' 
Nur Padhilah, Hamdan Juhannis, Sitti Nurpahmi, The Causal Factors $O f \ldots$

guide, so the students can be able to speak English in two-way communication. Therefore, one of the ways that need to be done is to know the causal factors of Bugis-Bone accent that affect the way the students from Bugis-Bone tribe speak English.

Accent refers to the way in which the speakers are producing different sound of speech. Bugis-Bone is known as one of the regions in the Bugis tribe area that has a strong/heavy accent. Related to that, the researcher interested in researching how the students from BugisBone tribe speak English because when the people from this tribe speak in other languages they sometimes use their local accent. Based on the statement above, the researchers intend to research the Bugis-Bone accent interfere on the pronunciation in English conversation.

\section{B. LITERATURE REVIEW}

Keichi Tajima and Robert Port (1996) conducted a research entitled Effect of Temporal Correction on Intelligibility of Foreign-Accented English which investigated the effect of temporal properties of speech on the intelligibility of utterances produced by nonnative English speaker. They focused on short English phrases that instrumentally modified by a native Chinese speaker comparing to the way the native English speaker spoke the same phrases. the result of this study concluded that if explicit training was provided on temporal properties of their speech, the intelligibility of foreign-English speaker may be enhanced.

The research entitled Difficulties Encountered by The Buginese Learners in Producing English Sounds by Sitti Nurpahmi (Nurpahmi, 2013). In her research, she found the difference and similarities of both Bugis and English in phoneme pronunciation. It becomes the causal factor of the English learner from Bugis-Bone to pronounce English words by analyzing Bugis phoneme which then compares it to English phoneme.

The researchers took the previous findings as a reference in taking the research and collecting the data that was recorded by doing observation and interview. One of the previous researches which held by Sitti Nurpahmi (Nurpahmi, 2013), was the main reference in collecting the data, because the researcher researched the causal factors of Bugis-Bone accent on the pronunciation in English conversation, so knowing the differences of the pronunciation of those both languages makes the researcher easier to describe the main problem of how this Bugis-Bone language as a mother tongue of the subjects can interfere the way they speak English in the situation of classroom and casual conversation. 
Volume 4, Number 01, June 2018

\section{Definition of Accent and Pronunciation}

a. Accent

Accent mostly defined as the same description as the dialect. People may think that their dialect is also their accent. These words refer to a certain way of speaking a language, resulting in being used interchangeably. People can distinguish a dialect from another dialect of a given language in lexical and phonological term. Dialect refers to the language varieties of social groups (Muhammad Asdam, 2012: 47). Whereas in Seidlhofer and Dalton (2001: 5) accent is the regional or social varieties which related to the sound level as phonology aspect where then affected to the social group high prestige.

\section{b. Pronunciation}

Pronunciation is the way in which a particular word is spoken as in Oxford Learners' Pocket Dictionary (2009: 352). According to Yates (2002) in Permana (2014) pronunciation refers to the speaker sounds production. Cook in Safa (2004:9) stated that pronunciation deals with a set of habit to produce sound of language. In other views, Jusman (2014:10) defined that pronunciation refers to the ability of producing comprehensible articulation. Based on the previous statements, the definition of the pronunciation is very closely related to a way of producing sound.

\section{RESEARCH METHOD}

The researchers adopted case studies which is one of the qualitative strategies. According to Creswell (in Sugiyono 2014: 228) qualitative research is a process for exploring and understanding the meaning of individual or group behavior. Case study is the strategy in which the researcher will explore in depth the event and the activities of one or more individual by collecting detailed information using a variety of data collection procedures (Sugiyono, 2014: 230).

The main instrument of this research was the researcher. The instrument in the qualitative research is buman instrument because the key for finding the result of the research is the researcher her/himself as Nasution (1988) in Sugiyono (2014:306) stated that there is no choice but the researcher is the instrument because the result cannot be determined surely. The other instruments were observation and interview.

Observation is the way the researchers collect the data by observing people and place John W. Creswell, 2012:213). Interview is the way the researcher ask one or more subjects with an open-ended question then record their answers (John W. Creswell, 2012:217). The tools that 
Nur Padhilah, Hamdan Juhannis, Sitti Nurpahmi, The Causal Factors $O f \ldots$

used to support these both activities (observation and interview) are Smartphone's camera, laptop, notebook, and mini tripod.

\section{FINDING AND DISCUSSION}

1. The different phoneme produce between Bugis native speaker and English native speaker in some areas of phoneme.

The first factor that becomes the causal factor of Bugis-Bone Accent interference on the pronunciation in English conversation is the different phoneme produce between Bugis native speaker and English native speaker in some areas of phoneme. The finding in Sitti Nurpahmi (Nurpahmi, 2013) shows that errors which produced by the Buginese learners in several areas of phonemes occurred because the phonemes which are not in their first language (Bugis language). Based on that, the researchers assume that another factor which becomes the interference on the pronunciation in English conversation is the differences of phoneme produced between Bugis and English. The researcher also found some phoneme that is difficult to be pronounced well by the subjects (STAIN English students), as follows:

a. Pronouncing $/ \mathrm{z} /$

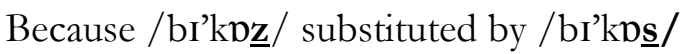

b. Pronouncing $/ \mathfrak{x} /$

Expansion /Ik'spæen $\int \mathrm{n} /$ substituted by /Ik'span $\int \mathrm{n} /$

c. Pronouncing / $\mathrm{s} / /$

For / fo:(r)/ substituted by / $\underline{\text { fov }} \mathbf{r} /$

d. Pronouncing $/ \mathrm{v} /$

Seven /'sevnn/ substituted by /sefnn/

e. Pronouncing / / $/$

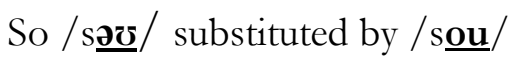

f. Pronouncing $/ \Theta /$

Think / $\underline{\boldsymbol{\theta}} \mathrm{I} \eta \mathrm{k} /$ substituted by / $\underline{\text { tink} / ~}$

g. Pronouncing $/ \delta /$

Thus / $\underline{\boldsymbol{\delta}} \Lambda \mathrm{s} /$ substituted by / $\underline{\mathbf{d}} \Lambda \mathrm{s} /$

2. Bugis-Bone Accents is a strong/heavy accent. 
Volume 4, Number 01, June 2018

The second category that becomes the causal factor of Bugis-Bone Accent that showed massively interfere the subjects' English pronunciation is because this accent which becomes the dominant chosen language that Bugis-Bone people usually use to communicate with each other is a strong/heavy accent. Indeed, this Bugis-Bone was known as a strongest/heaviest accent among other accents in Bugis tribe. It even has many different accent in every area in Bone regency that has its own character.

\section{E. CONCLUSSION}

The researchers finally found several points after doing some activities of data collection that become the causal factors of Bugis-Bone Accent interference on the pronunciation in English conversation, as follows:

1. The different phoneme produced by Bugis native speakers and English native speaker in some areas of phoneme caused the native speaker of Kabupaten Bone sometimes difficult to pronounce English words and adjust the English accent well.

2. Bugis-Bone Accents is a strong/heavy accent.

Based on the information above, the results show that the different produce in some areas of phoneme between Bugis native speaker and English native speaker is the causal factors which interfere the students' English pronunciation in conversation, and the subjects' natural habit of speaking their first language in casual conversation. Thus, the researcher proposes some advices to the teachers and the students which are the Bugis native speaker, especially to the students who live in the Bugis-Bone area that has a strong/heavy accent, as follows:

a. To the teachers

1. The teacher shall be aware of the students' first language accent interference when they teach English conversation.

2. The teacher must support the students by attending to the way they pronounce the English word.

b. To the students

1. The students shall be aware of their first language accent interference when they speak English conversation.

2. A basic problem like the different phoneme produce between Bugis native speaker and English native speaker is not a big deal for being good in pronouncing English words, because some people have found the ways to solve the problem, so the students shall do the same. 
Nur Padhilah, Hamdan Juhannis, Sitti Nurpahmi, The Causal Factors $O f \ldots$

\section{REFERENCES}

Asdam, Muhammad. (2012) "Pengantar Ilmu Sosiolinguistik". Makassar: CV Awal.

Creswell, John. W. (2012) Educational Research:Planning, Conducting, and Evaluating Quantitative and

Qualitative Research. Cet.VI; Boston: Pearson Education.

Nurpahmi, S. (2013). Difficulties Encountered By The Buginese Learners In Producing

English Sounds. Lentera Pendidikan: Jurnal Ilmu Tarbiyah Dan Keguruan, 16(1), 83-90.

Nurpahmi, S. (2014). English for Sepecific Puposes: An Integrated Approach. Makassar: ALauddin

University Press.

Nurpahmi, S. (2017). Teacher Talk In Classroom Interaction. ETERNAL (English, Teaching, Learning, and Research Journal), 3(1), 34-43.

Nurpahmi, S. (2014). English for Specific Purposes: An Integrated Approach. Makassar: Alauddin University Press.

Nurpahmi, S., Rahman, M. A., \& Salija, K. (2018). Bilingual-based Instruction in Teaching

English for Academic Purposes at Islamic University. Journal of Language Teaching and Research, 9(3), 620-628.

Oxford (2011) Oxford Learner's Pocket Dictionary. New York: Oxford University Press.

Permana, Andhika. (2014) 'Enhancing the Students' Mastery of Pronunciation through Audiovisual Media at the Second Year of Madrasah Aliyah Negeri Baranti Kabupaten Sidrap”. Thesis. Makassar: Tarbiyah and Teaching Science Faculty of UIN Alauddin Makassar.

Seidlhofer, Barbara and Christiane Dalton. (2001) Pronunciation. New York: Oxford University Press.. http://books.google.co.id.html (28 Oktober 2017).

Shafa. (2003) "The Correlation between the Fluency in Speaking English and the Vocabulary of the Second Year Students' of Madrasah Aliyah Putri As'adiyah Sengkang. Thesis. Makassar: Tarbiyah and Teaching Science Faculty of UIN Alauddin Makassar.

Sugiyono. (2015). Metode Pendidikan Pendidikan Pendekatan Kuantitatif, Kualitatif, dan R\&D. Cet. XXII; Bandung: Penerbit Alfabeta.

------. (2014) Cara Mudah Menyusun: Skripsi, Tesis, dan Disertasi. Cet.II; Bandung: Penerbit Alfabeta.

Tajima, Keiichi and Robert Port.(1996). "Effects of Temporal Correction on Intelligibility of Foreign-Accented English". Journal of Phonetic: p. 224-401. 